\title{
C-MET Gene Amplification
}

National Cancer Institute

\section{Source}

National Cancer Institute. C-MET Gene Amplification. NCI Thesaurus. Code C43532.

A molecular genetic abnormality indicating the presence of multiple copies of the MET gene. 